\title{
HUBUNGAN PEMAHAMAN IBU TENTANG PESAN GIZI SEIMBANG DENGAN STATUS GIZI ANAK PRASEKOLAH DI TK IT AULADUNA KOTA BENGKULU
}

\author{
The Relationship between Understanding of Mothers about Balanced Nutrition and Nutritional \\ Status of Preschool Children at IT Auladuna Kindergarten in Bengkulu City \\ Emy Yuliantini, Kusdalinah, Andhika Putri Yuliani \\ Politeknik Kesehatan Kemenkes Bengkulu, Jurusan Gizi, Jl. Indragiri No.03 Padang Harapan Bengkulu \\ E-mail: emyardi08@yahoo.com
}

\begin{abstract}
Mother's knowledge about balanced nutrition is important, since the role of the mother in the family is as the manager of food service. The quantity and quality of food and beverages consumed in the family level will affect health of all family's members and finally it will affect communities as well. To keep the body healthy and is protected from chronic diseases or non-communicable diseases (NCDs) related to nutrition, individual diet needs to be improved to nutritionally balanced through consumption. Efforts have been made in monitoring the nutritional status and a set of good diet. This study aimed to explore understanding of mothers about balanced nutrition and nutritional status of preschool children at IT Auladuna kindergarten in Bengkulu City. It was an observational design with cross sectional study, take place at IT Auladuna kindergarten in Bengkulu City. The study population was a preschooler. Sampling was taken using proportional sample size (PPS) of 68 people. Data on maternal knowledge were collected through interviews using questionnaires, Body Weight (BW) and height of children were measured using standarized equipments. Based on the chi-square test results showed that mother's knowledge about tumpeng/cone balanced nutrition had a significant relationship to nutritional status of preschooler ( $p \leq$ 0.05), whereas knowledge about My Plate is not associated with nutritional status of preschooler. This study concluded that only the knowledge of mothers about cone-balanced nutrition was significant to nutritional status of their preschool children at IT Auladuna kindergarten in Bengkulu City.
\end{abstract}

Keywords: nutritional status, knowledge of mother, balanced nutrition, preschool children

\section{ABSTRAK}

Pengetahuan ibu tentang gizi seimbang sangatlah penting, mengingat peran ibu dalam keluarga sebagai pengelola makanan. Ibu yang tidak tahu gizi makanan, akan menghidangkan makanan yang tidak seimbang gizinya. Agar tubuh tetap sehat dan terhindar dari berbagai penyakit kronis atau penyakit tidak menular (PTM) terkait gizi, maka pola makan masyarakat perlu diarahkan ke konsumsi gizi seimbang. Upaya yang dilakukan dalam memantau status gizi dengan mengatur pola makan yang baik. Penelitian ini bertujuan mengetahui pemahaman ibu tentang tumpeng gizi seimbang dengan status gizi anak prasekolah di TK IT Auladuna Kota Bengkulu. Desain penelitian ini adalah observasional dengan metode cross sectional di TK IT Auladuna Kota Bengkulu. Populasi penelitian adalah anak prasekolah. Pengambilan sampel dilakukan dengan cara proporsional sampel sebanyak 68 orang. Data tentang pengetahuan ibu dilakukan dengan wawancara menggunakan kuesioner dan data pengukuran BB dan TB anak dilakukan dengan melakukan penimbangan dan pengukuran menggunakan alat terstandar. Berdasarkan uji chi-square diperoleh hasil bahwa hanya pengetahuan tentang tumpeng gizi seimbang ada hubungan nyata dengan status gizi $(p<0,05)$, namun tidak pada pengetahuan tentang piring makanku. Pengetahuan tentang gizi seimbang perlu ditingkatkan pada semua kelompok masyarakat khususnya pada ibu yang mempunyai anak prasekolah.

Kata kunci: status gizi, pemahaman ibu, gizi seimbang, anak prasekolah

\section{PENDAHULUAN}

edoman Gizi Seimbang telah dikenalkan dan disosialisasikan kepada masyarakat lebih dari 15 tahun lalu, namun masih banyak masalah gizi yang belum teratasi yaitu gizi lebih dan gizi kurang. Kendala dalam sosialisasi Gizi Seimbang untuk merubah perilaku gizi masyarakat ke arah perilaku gizi seimbang belum sepenuhya tercapai. Konsumsi 
pangan belum seimbang baik kuantitas maupun kualitasnya, dan perilaku hidup bersih dan sehat belum memadai. ${ }^{1}$ Pedoman Gizi Seimbang 2014 berisi 4 prinsip mengatur pola hidup sehat tidak hanya dari aspek makanan (keaneka ragaman sesuai kebutuhan dan keamanan), tetapi juga aspek kesehatan lainnya yaitu kebersihan, aktivitas fisik atau olah raga, dan berat badan ideal. ${ }^{2}$

Gangguan gizi sering terjadi karena kurang pengetahuan mengenai kebutuhan anak dan makanan tambahan yang bergizi, ketidaktahuan menyiapkan makanan tambahan dari bahanbahan lokal yang bergizi, dan kemiskinan, sehingga kurang mampu menyediakan makanan yang bergizi. ${ }^{3}$ Pengetahuan ibu tentang gizi seimbang sangatlah penting, mengingat peran ibu dalam keluarga sebagai pengelola makanan. Ibu yang tidak tahu gizi makanan, akan menghidangkan makanan yang tidak seimbang gizinya. ${ }^{4}$ Penelitian Ikhwansyah (2004) tentang faktor-faktor yang berhubungan dengan status gizi anak balita di Kecamatan Kertak Hanyar Kabupaten Banjar Provinsi Kalimantan Selatan menunjukkan bahwa pengetahuan ibu, pekerjaan ibu, asupan makan dan imunisasi mempunyai hubungan dengan status gizi balita. ${ }^{5}$

Pola konsumsi yang dianjurkan di Indonesia sesuai dengan kaidah kesehatan adalah diarahkan pada pola konsumsi yang lebih beragam, bergizi dan berimbang yang biasa disebut dengan menu seimbang yang terdiri dari makanan pokok, lauk hewani dan nabati, sayur, buah dan susu. Akan tetapi pada kenyataannya masih banyak keluarga yang belum mampu untuk menerapkan pola konsumsi tersebut dalam menu sehari-hari. Hal ini sangat terkait dengan daya beli, ketersediaan pangan, faktor ekonomi, pendidikan dan sosial budaya. ${ }^{6}$

Menurut Riskesdas 2013 menunjukkan bahwa prevalensi pendek di provinsi Bengkulu sekitar 30 persen terdiri dari 14 persen sangat pendek dan 16 persen pendek. Sedangkan prevalensi kurus (menurut IMT/U) di provinsi Bengkulu sekitar 8 persen (3\% sangat kurus dan $5 \%$ kurus). Selain itu prevalensi masalah gizi gemuk di provinsi Bengkulu sekitar 23 persen terdiri dari 15 persen gemuk dan 8 persen sangat gemuk (Kemenkes, 2013). Disamping masih banyak yang kekurangan gizi, masalah gizi lebih juga meningkat. Karena itu perlu ditingkatkan lagi perhatian terhadap masalah gizi ganda di Indonesia. ${ }^{7}$

Masa balita merupakan masa kritis dalam upaya menciptakan sumber daya manusia yang berkualitas. Gagal tumbuh yang terjadi akibat kurang gizi pada masa-masa emas ini akan berakibat buruk pada kehidupan berikutnya yang sulit diperbaiki. Anak yang menderita kurang gizi (Stunted) berat mempunyai ratarata IQ 11 poin lebih rendah dibandingkan ratarata anak-anak yang tidak stunted (World Bank, 2006). ${ }^{8}$ Oleh karena itu, perlu dilakukan penelitian pemahaman ibu tentang gizi seimbang dengan status gizi anak prasekolah. Tujuan penelitian adalah untuk mengetahui hubungan pemahaman ibu tentang gizi seimbang dengan status gizi anak prasekolah berdasarkan IMT/U di TK IT Auladuna Kota Bengkulu.

\section{METODE PENELITIAN}

Desain penelitian ini yang digunakan adalah observasional dengan pendekatan cross sectional. Metode penelitian dengan pendekatan kuantitatif. Penelitian ini dilakukan untuk mengetahui hubungan antara variable bebas adalah pemahaman ibu, variable terikat adalah status gizi. Populasi dalam penelitian ini adalah ibu yang mempunyai anak prasekolah usia 5-6 tahun sebanyak 210 orang anak. Sampel dalam penelitian ini adalah sebanyak 68 orang yang diambil menggunakan teknik proporsional sampel yaitu untuk menentukan besar sampel dari setiap kelas yang jumlahnya tidak sama. Kemudian digunakan teknik simple random sampling untuk menentukan sampel dari setiap kelas.

Penelitian ini dilakukan di TK IT Auladuna Kota Bengkulu pada bulan Januari tahun 2015. Data tentang pemahaman ibu dinilai berdasarkan kuesioner pertanyaan tentang tumpeng gizi seimbang dan piring makanku. Jawaban atas pertanyaan tersebut kemudian diberi skor dijumlah dan dihitung persentase jawaban yang benar secara keseluruhan. Pemahanan dikatagorikan tinggi apabila persentase skor benar lebih dari 60persen dan rendah apabila persentase skor benar kurang dari 60persen. ${ }^{9}$ Data pengukuran tinggi badan dilakukan dengan menggunakan microtoise dengan ketelitian $0.1 \mathrm{~cm}$; data cara pengukuran berat badan anak diukur menggunakan 
timbangan injak dengan ketelitian $0,1 \mathrm{~kg}$. Status gizi ditentukan menurut IMT/U dengan katagori Normal $(-2 \leq Z$-skor $<+2)$ dan katagori tidak normal ( Gemuk dan sangat gemuk : Z skor $\geq+$ 2 , Kurus $-3 \leq Z$ skor $<-2$, sangat kurus $Z$ - skor $<$ 3). Data diolah menggunakan program SPSS. Analisis data dilakukan pada univariat dan bivariat. Pengujian statistik dilakukan dengan menggunakan uji Chi-Square dengan tingkat kepercayaan $95 \%$.

\section{HASIL}

\section{Pemahaman Ibu tentang Gizi Seimbang}

Pemahaman ibu tentang menu dikategorikan menjadi tinggi dan rendah. Berdasarkan analisis univariat, diperoleh distribusi frekuensi pada Tabel 1. Berdasarkan Tabel. 1 dapat dilihat bahwa sebagian besar ibu
$(52,9 \%)$ memiliki pengetahuan yang tinggi tentang gizi seimbang.

\section{Status Gizi}

Status gizi anak prasekolah di TK IT Auladuna Kota Bengkulu Tahun 2015 dikategorikan menjadi normal dan tidak normal. Berdasarkan analisis univariat, diperoleh distribusi frekuensi seperti pada Tabel 2. Berdasarkan Tabel 2 dapat dilihat bahwa sebagian besar anak $(52,9 \%)$ memiliki status gizi yang normal. Selain itu didapat pula anak dengan status gizi tidak normal dimana anak yang berstatus gizi kurus dan sangat kurus didapatkan hasil $(4,5 \%)$ sedangkan anak dengan status gizi lebih $(42,6 \%)$.

Tabel 1

Distribusi Frekuensi Pemahaman Ibu Tentang Gizi Seimbang di TK IT Auladuna Kota Bengkulu Tahun 2015

\begin{tabular}{lcc}
\hline Pemahaman Ibu tentang Gizi Seimbang & $\mathrm{n}$ & $\%$ \\
\hline Rendah & 32 & 47.1 \\
Tinggi & 36 & 52.9 \\
\hline Total & 68 & 100 \\
\hline
\end{tabular}

Tabel 2

Distribusi Frekuensi Status Gizi Anak Prasekolah Berdasarkan IMT/U di TK IT Auladuna Kota Bengkulu Tahun 2015

\begin{tabular}{lcc}
\hline Status Gizi & $\mathrm{n}$ & $\%$ \\
\hline Tidak Normal & 32 & 47.1 \\
Normal & 36 & 52.9 \\
\hline Total & 68 & 100 \\
\hline
\end{tabular}

Tabel 3

Hubungan Pemahaman Ibu Tentang Gizi Seimbang dengan Status Gizi Anak Prasekolah Berdasarkan IMT/U di TK IT Auladuna Kota Bengkulu Tahun 2015

\begin{tabular}{|c|c|c|c|c|c|c|c|c|}
\hline \multirow{3}{*}{$\begin{array}{l}\text { Pemahaman Ibu tentang } \\
\text { Gizi Seimbang }\end{array}$} & \multicolumn{4}{|c|}{ Status Gizi Anak } & \multicolumn{2}{|c|}{ Total } & \multirow{3}{*}{$\begin{array}{c}\text { Nilai } \\
p\end{array}$} & \multirow{3}{*}{ OR } \\
\hline & \multicolumn{2}{|c|}{ Tidak Normal } & \multicolumn{2}{|c|}{ Normal } & \multirow{2}{*}{$n$} & \multirow{2}{*}{$\%$} & & \\
\hline & $\mathrm{n}$ & $\%$ & $\mathrm{n}$ & $\%$ & & & & \\
\hline Rendah & 21 & 65.6 & 11 & 34.4 & 32 & 100 & 0.008 & 4.339 \\
\hline Tinggi & 11 & 30.6 & 25 & 69.4 & 36 & 100 & & \\
\hline
\end{tabular}




\section{Pemahaman ibu tentang Gizi Seimbang dengan Status Gizi}

Berdasarkan penelitian diketahui ada hubungan antara pemahaman ibu tentang gizi seimbang dengan status gizi anak. Secara rinci dapat dilihat pada Tabel 3. Berdasarkan Tabel 3 dapat dilihat bahwa sebagian besar ibu 21 orang $(69,4 \%)$ yang berpemahaman tinggi tentang gizi seimbang memiliki anak dengan status gizi normal dibanding dengan pemahaman ibu yang rendah. Berdasarkan uji kai-kuadrat bahwa ada hubungan yang signifikan antara pemahaman ibu tentang gizi seimbang dengan status gizi anak $(p=0,008)$. Nilai $\mathrm{OR}=4.33$ menunjukkan bahwa ibu yang mempunyai pemahaman tentang gizi seimbang rendah memiliki peluang anak dengan status gizi tidak normal 4, 33 kali lebih besar dibanging dengan ibu yang mempunyai pemahaman tinggi.

\section{BAHASAN}

\section{Pemahaman Ibu tentang Gizi Seimbang}

Walaupun sebagian besar ibu sudah memiliki pemahaman tentang gizi seimbang tetapi belum mengetahui standar kebutuhan dan standar porsi bahan makanan seperti laukpauk dan buah-buahan dalam sehari. Laukpauk dan sayuran merupakan bahan makanan yang penting bagi kesehatan apalagi pada masa pertumbuhan anak, dimana protein pada lauk-pauk sebagai zat pembangun serta memelihara sel-sel dan jaringan tubuh. sedangkan vitamin dan mineral yang tekandung dalam sayuran sebagai zat pengatur pertumbuhan dan pemeliharaan fungsi tubuh dalam kehidupan..$^{10}$ seperti yang diungkapkan oleh Notoatmodjo (2003) bahwa pengetahuan seseorang terhadap objek mempunyai intensitas dan tingkat yang berbeda-beda. Tingkat pengetahuan yang beda-beda pada setiap orang ini terjadi karena berbagai faktor, misalnya umur, pendidikan, pekerjaan, pengalaman, dan lingkungan. ${ }^{11}$

Pemahaman ibu tentang makanan bergizi merupakan salah satu faktor yang dapat mempengaruhi kesehatan, memberikan daya adaptasi yang tinggi untuk tumbuh kembang anak. ${ }^{12}$ Apabila ibu memiliki pengetahuan yang baik tentang gizi maka kejadian gizi kurang dan gizi buruk akan dapat dihindari. ${ }^{13}$ Seorang ibu seharusnya lebih mengerti tentang cara pemilihan makanan yang baik bagi anak untuk kelangsungan tumbuh kembang anaknya. ${ }^{9}$

Penelitian Rodrigo et al.(2003) di Spanyol yang menyatakan pemahaman yang kurang menunjukan bahwa anak-anak di Spanyol cenderung menyukai makanan sumber karbohidrat dan protein dibandingkan sumber serat $^{19}$. Untuk mengatasi masalah tersebut ibu dapat mencari informasi mengenai gizi dan porsi bahan makanan dalam sekali makan melalui, media cetak, penyuluhan, dan juga melalui internet.

Anjuran jumlah porsi menurut kecukupan energi untuk kelompok umur seperti anak prasekolah dengan kebutuhan energi sebesar 1600 kkal dalam sehari. $^{1}$

\section{Status Gizi}

Status gizi adalah keadaan kesehatan individu-individu atau kelompok-kelompok yang ditentukan oleh derajat kebutuhan fisik akan energi dan zat-zat gizi lain yang diperoleh dari pangan dan makanan yang dampak fisiknya diukur secara antropometri.14 Untuk memperoleh status gizi yang baik, antara asupan zat gizi dan pengeluarannya harus ada keseimbangan. ${ }^{15}$

Faktor yang bisa mempengaruhi status gizi balita, yaitu ketidaktahuan akan hubungan makanan dan kesehatan ${ }^{16}$. Ketidaktahuan ibu akan kebutuhan gizi anak bisa mengakibatkan asupan gizi pada anak tidak terpenuhi dengan baik maka proses tumbuh kembang anak akan terhambat, anak bisa mengalami penyakit kurang gizi. ${ }^{17}$

\section{Hubungan antara Pemahaman lbu tentang Gizi Seimbang dengan Status Gizi}

Hasil penelitian ini sejalan dengan penelitian Gunarti(2005) bahwa pengetahuan gizi ibu menentukan segala sesuatu yang dimakan oleh anak karena pengetahuan mempengaruhi perilaku pemilihan makanan yang akan berpengaruh dengan asupan dan status gizi seseorang..$^{18}$

Pentingnya pengetahuan gizi didasarkan pada tiga kenyataan yaitu: a). Status gizi yang cukup adalah penting bagi kesehatan dan kesejahteraan. b). Setiap orang hanya akan 
cukup zat gizi, jika makanan yang dimakannya mampu menyediakan zat gizi yang diperlukan untuk pertumbuhan yang optimal, pemeliharaan, dan sebagai energi. c). IImu gizi memberikan fakta-fakta yang perlu sehingga penduduk dapat belajar menggunakan pangan dengan baik bagi perbaikan gizi. ${ }^{14}$

Penelitian Osei et al (2008) menunjukkan bahwa praktek gizi ibu menjadi faktor penting dalam penentuan kebutuhan gizi dan status gizi anak, semakin tinggi tingkat pengetahuan gizi ibu semakin baik status gizi anak dan semakin rendah tingkat pengetahuan ibu maka status gizi anaknya mengalami gizi kurang maupun gizi buruk. ${ }^{20}$

Hal yang sama dikemukakan Khairiyah (2001), bahwa ada hubungan pengetahuan ibu dengan status gizi anak balita. Pengetahuan ibu cenderung mempunyai korelasi yang signifikan terhadap pemilihan dan pengolahan bahan makanan untuk keluarganya. Pengetahuan gizi yang baik mempunyai hubungan dalam memilih bahan makanan yang akan diberikan kepada anak balita. Tingkat pengetahuan tidak selalu berkorelasi dengan tindakan yang dilakukan. ${ }^{10}$

Menurut Marimbi (2010) masalah gizi karena kurang pengetahuan dan keterampilan dibidang memasak menurunkan konsumsi anak, keragaman bahan dan keragaman jenis masakan yang mempengaruhi kejiwaan misalnya kebosanan. Seorang ibu sebagai pengelola atau penyelenggara makanan dalam keluarga mempunyai peranan yang besar dalam peningkatan status gizi anggota keluarga.

Gizi sangat penting bagi anak untuk tumbuh kembangnya, status gizi anak tergantung dari jumlah asupan makanan yang diberikan oleh ibu sesuai dengan kebutuhan gizi anak. Selain itu penimbangan berat badan penting dilakukan untuk memantau status gizi anak, sehingga bisa dilakukan penanganan secara dini jika terjadi ketidakseimbangan gizi. ${ }^{16}$

\section{SIMPULAN DAN SARAN}

\section{Simpulan}

Sebagian besar ibu mempunyai pemahaman tinggi tentang gizi seimbang. Sebagian besar anak mempunyai status gizinya normal. Ada hubungan pemahaman ibu tentang gizi seimbang dengan status gizi anak prasekolah berdasarkan IMT/U.

\section{Saran}

Seharusnya ibu memperhatikan porsi makanan anak seperti makanan pokok, laukpauk, sayur dan buah-buahan sesuai dengan kebutuhan sehari. Peningkatan pemahaman ibu tentang gizi seimbang dapat dilakukan dengan Mencari informasi melalui penyuluhan, media cetak, konsultasi dan lain sebagainya.

Agar tidak bertambah masalah gizi lebih dan kurang, maka sekolah mulai memikirkan penanganan kasus gizi lebih siswa melalui program UKS, seperti penjaringan siswa berstatus gizi lebih atau kurang, upaya menanggulangan kesehatan pada siswa berstatus gizi lebih atau kurang di sekolah agar dapat dirujuk ke Puskesmas atau Rumah Sakit. Pihak sekolah perlu melakukan program pemantauan status gizi pada anak setiap awal semester atau berkala sehingga dapat dilakukan deteksi dini gangguan pertumbuhan pada anak.

\section{RUJUKAN}

1. Kementerian Kesehatan RI. Pedoman Gizi Seimbang. Jakarta.2014

2. Soekirman.Mencegah Beban Ganda Masalah Gizi dengan Gizi Seimbang. Bogor: KFI Newsletter.2014

3. Soetjiningsih.Tumbuh Kembang Anak. Jakarta: EGC.2008.

4. Marimbi, Hanum.Tumbuh Kembang, Status Gizi \& Imunisasi Dasar pada Balita. Yogyakarta: Nuha Medika. 2010

5. Ikhwansyah. Faktor-faktor Yang Berhubungan Dengan Status Gizi Anak Balita di Kecamatan Kertak Hanyar Kabupaten Banjar Provinsi Kalimantan Selatan. Tesis, UGM : Yogyakarta.2004

6. FKM UI. Gizi dan Kesehatan Masyarakat. Raja Grafindo Persada: Jakarta.2007

7. Departemen Kesehatan RI. Badan Penelitian dan Pengembangan Kesehatan (Balitbang). Riset Kesehatan Dasar (Riskesdas) 2013, Laporan Nasional. Balitbang Depkes, Jakarta.2013

8. World Bank. Repositioning Nutrition as Central to Devolopment A Strategy for Large-Scale Action. Washington DC : USA.2006 
9. Khomsan, A. Peran Pangan dan Gizi untuk Kualitas Hidup. Jakarta: PT Grasido . 2004

10. Khairiyah. Analisis Hubungan Pengelola dan Penyajian Makanan Terhadap Status Gizi Balita di Daerah pesisir Kecamatan Maros Baru Kabupaten Maros, Jurnal Media Nusantara.2000

11. Notoatmojo, S. Pengantar Pendidikan Kesehatan dan IImu Perilaku Kesehatan. Edisi pertama, Yogyakarta.2003

12. Sandjaja .Penyimpangan positip (portive doviance) status gizi anak balita dan faktor-faktor yang mempengaruhi. Di buka tanggal 5 Februari 2015 dari : http://digilitbangdepkes.go.id/go.php?id =jkpkbpk-gdl-les-2000-sandjaja-ggbbalita.2000

13. Sjahmien, M.Pemeliharaan gizi bayi dan balita. Jakarta: Bhratara Niaga Media.2002

14. Suhardjo. Berbagai Cara Pendidikan Gizi. Jakarta: EGC.2003

15. Prasetyowati, Irma dan Inong Retno Gunanti. Hubungan Antara Tingkat Konsumsi (Energi dan Protein) dan Tingkat Aktivitas Fisik dengan Status Gizi Lebih Pada Siswa Sekolah Dasar Dengan Sistem Full Day School di Yayasan Pendidikan Al Muslim, Sidoarjo, Jawa Timur. Yogyakarta :
Pertemuan IImiah Nasional (PIN) Dietetic Update.2003

16. Morani, Winda.Hubungan Pengetahuan Ibu Tentang Makanan Bergizi Terhadap Status Gizi Balita di Kecamatan Kotanopan, Kabupaten Mandailing Natal. Skripsi. Medan: Fakultas Kedokteran Universitas Sumatera Utara.2008

17. Sediaoetama, Achmad Djaeni. IImu Gizi I. Jakarta: Dian Rakyat.2008

18. Gunarti, RI, Devi RS, Adriani.M. pemerdayaan kader posyandu melalui penerapan metode konseling gizi dalam upaya meningkatkan kualitas pembinaan program keluarga mandiri sadar gizi (Kadarzi) jurnal bulletin penelitian system kesehatan.2005.8:4758

19. Rodrigo P,Ribas L, Serre-majem Li, Arnceta J. Food preference of Spanish children and young people :the end kid study. European Journal of clinical Nutrition,57.Suppl 1,545-548. 2003

20. Osei A, Pandey P, Spiro D, Nielson J, Sherstha R, Talukder Z,Quin V, Haselow N. House hold food insecurity and nutritional status of childen aged 6 to 23 months in kailali district of Nepal. Food and Nutrition Bulletin,31 (4) 483494.2010. 